\title{
New Rules on Patient's Safety and Professional Liability for the Italian Health Service
}

\author{
Sara Albolino ${ }^{1}$, Tommaso Bellandi ${ }^{1}$, Simone Cappelletti ${ }^{2}$, Marco Di Paolo ${ }^{4}$, Vittorio Fineschi ${ }^{2,3^{*}}$, \\ Paola Frati ${ }^{2,3}$, Caterina Offidani ${ }^{4}$, Michela Tanzini ${ }^{1}$, Riccardo Tartaglia ${ }^{1}$ and Emanuela Turillazzi ${ }^{5}$
}

\author{
${ }^{I}$ Regional Centre for Clinical Risk Management and Patient Safety, Florence, Italy; ${ }^{2}$ Department of Anatomical, Histo- \\ logical, Forensic and Orthopaedic Sciences, Sapienza University of Rome, Rome, Italy; ${ }^{3}$ IRCCS Neuromed, Pozzilli, \\ Italy; ${ }^{4}$ Unit of Legal Medicine, Bambino Gesù Children's Hospital, IRCCS, P.za Sant'Onofrio 4, Rome, Italy; ${ }^{5}$ Section of \\ Legal Medicine, Department of Surgical Pathology, Medical, Molecular and Critical Area, University of Pisa, Pisa, \\ Italy
}

\begin{abstract}
Background: The phenomenon of clinical negligence claims has rapidly spread to United States, Canada and Europe assuming the dimensions and the severity of a pandemia. Consequently, the issues related to medical malpractice need to be studied from a transnational perspective since they raise similar problems in different legal systems.
\end{abstract}

A R T I C L E H I S T O R Y

Received: October 26, 2018 Revised: November 27, 2018 Accepted: December 16, 2018

DOI:

$10.2174 / 1389201020666190408094016$
Objective: Over the last two decades, medical liability has become a prominent issue in healthcare policy and a major concern for healthcare economics in Italy. The failures of the liability system and the high cost of healthcare have led to considerable legislative activity concerning medical malpractice liability, and a law was enacted in 2012 (Law no. 189/2012), known as the "Balduzzi Law".

Results: The law tackles the mounting concern over litigation related to medical malpractice and calls for Italian physicians to follow guidelines. Briefly, the law provided for the decriminalisation of simple negligence of a physician on condition that he/she followed the guidelines and "good medical practice" while carrying out his/her duties, whilst the obligation for compensation, as defined by the Italian Civil Code, remained. Judges had to consider that the physician followed the provisions of the guidelines but nevertheless caused injury to the patient.

Conclusion: However, since the emission of the law, thorny questions remain which have attracted renewed interest and criticism both in the Italian courts and legal literature. Since then, several bills have been presented on the topic and these have been merged into a single text entitled "Regulations for healthcare and patient safety and for the professional responsibility of healthcare providers".

Keywords: Medical liability, patient safety, risk management, Italian law 24/2017, quality of health care, malpractice claims.

\section{INTRODUCTION}

The catalyst for the tremendous rise in public concern was the publication of the report: To Err is Human: Building a Safer Health System, where the impressive quantitative dimension of adverse events was denounced for the first time.

Starting from this report, many countries developed studies aimed to analyze the rates of adverse events in healthcare. In Italy, a recent retrospective study point out rates of adverse events of $5,17 \%$, also determining the difference between Local Hospitals and Teaching Hospitals [1].

*Address correspondence to this author at the Department of Anatomical, Histological, Forensic and Orthopaedic Sciences, Sapienza University of Rome, Rome, Italy; Tel: +390649912722; Fax: +390649912097;

E-mail: vfinesc@tin.it
The phenomenon of clinical negligence claims originated in the United States has rapidly spread to Canada and Europe, assuming the dimensions and the severity of a pandemia. Consequently, the issues related to medical malpractice need to be studied from a transnational perspective since they raise similar problems in different legal systems [2].

Over the last two decades, medical professional liability has become a prominent issue in healthcare policy and a major concern for healthcare economics in Italy. One indicator of the evolution of malpractice litigation is the report of the $\mathrm{Na}$ tional Association of Italian Insurance Companies (ANIA). According to this source, the number of claims filed in 2012 were 31,200 ; of these, 19,436 were against hospitals. The direct Italian medical liability insurance business was estimated at $€ 552$ million in $2014,50 \%$ being accounted for by 
institutional policies and $50 \%$ by individual policies. Over the period from 2004 to 2014, total premiums in the medical malpractice insurance sector recorded an average annual growth of 5.2\% (2.4\% for healthcare institutions and 9.4\% for individual practitioners) [3]. According to the National Agency for Regional Health Services (AGENAS), the costs of this judicial 'war machine' amount to nearly $1 \%$ of the Italian gross domestic product (GDP), i.e. about 10 billion euro a year [4]. Statistics also show that defensive medicine profoundly affects current medical practice among Italian physicians and has a considerable social economic impact [5-10]. According to the recent estimates by the University of Verona, reported in October 2014, the cost of defensive medicine in Italy now accounts for $10 \%$, equivalent to about 13 billion euro of overall healthcare spending [11].

The failures of the liability system and the high cost of healthcare have led to considerable legislative activity concerning medical malpractice liability, and a law was enacted in 2012 (law no. 189/2012), known as the "Balduzzi law" [12]. The law tackles the mounting concern over litigation related to medical malpractice and calls for Italian physicians to follow guidelines. Briefly, the law provided for the decriminalisation of simple/ordinary negligence of a physician on condition that he/she followed the guidelines and "good medical practice" accredited by the scientific community while carrying out his/her duties, whilst the obligation for compensation, as defined by the Italian Civil Code, remained. Judges had to consider that the physician followed the provisions of the guidelines but nevertheless caused injury to the patient [13].

However, since the emission of the law, thorny questions remain which have attracted renewed interest and criticism both in the Italian courts and legal literature. Since then, several bills have been presented on the topic and these have been merged into a single text entitled "Regulations for healthcare and patient safety and for the professional responsibility of healthcare providers".

\section{THE NEW LAW ON PATIENT SAFETY AND MED- ICAL LIABILITY}

With Law no. 24 (8 March 2017), known as "Law Gelli", which came into force on 1 April 2017, the Italian Parliament reformed the rules governing liability for medical malpractice and patient safety.

The first articles of the law aim to construct a system of protection for patients (protection which is inevitable given the risks which are intrinsically linked to healthcare) thus shaping a sensitive, virtuous approach which aims to direct the work of healthcare professionals towards the best results for the patient.

The law, which protects patients on the one hand and healthcare professionals on the other, has the aim of smoothing and facilitating the relationship between them. It focuses attention both on safety during treatment as well as any later stages should the outcome of medical care result in harm to the patient attributable to inadequate professional conduct. The law is an attempt to achieve a "comprehensive" reform, meaning an overall improvement in the dimensions of quality of care, patient safety and the medical liability system, aiming at making healthcare safe for both clients and health service staff.

The law is divided into 18 articles, most of which embody substantive changes to the pre-existing Italian health, medical liability and insurance systems. Table 1 provides a succinct outline of the articles to illustrate the law's scope. In this paper, we will outline key reforms focusing on patients' safety and medical liability.

Table 1. The essential structure of law 24/2017.

\begin{tabular}{|c|c|c|}
\hline Article & Name & Purpose \\
\hline $\begin{array}{c}\text { Article } \\
1\end{array}$ & Health care safety & $\begin{array}{l}\text { To improve the quality and efficien- } \\
\text { cy of health care system }\end{array}$ \\
\hline $\begin{array}{l}\text { Article } \\
\quad 2\end{array}$ & $\begin{array}{l}\text { Institution of regional or } \\
\text { provincial ombudsman } \\
\text { and regional centres of } \\
\text { health risk management } \\
\text { and patient safety }\end{array}$ & $\begin{array}{l}\text { To expand, at different levels (re- } \\
\text { gional) and to provide all available } \\
\text { information on health system risks. }\end{array}$ \\
\hline $\begin{array}{l}\text { Article } \\
3\end{array}$ & $\begin{array}{l}\text { Institution of a national } \\
\text { observatory of good } \\
\text { practices on health } \\
\text { safety }\end{array}$ & $\begin{array}{l}\text { To create a national collecting data } \\
\text { program and promoting initiatives to } \\
\text { improve safety and quality of care }\end{array}$ \\
\hline $\begin{array}{c}\text { Article } \\
4\end{array}$ & Transparency & $\begin{array}{l}\text { To promote transparency in health } \\
\text { care system and ensure patient's' } \\
\text { right to full access to all information } \\
\text { in their medical records }\end{array}$ \\
\hline $\begin{array}{c}\text { Article } \\
5\end{array}$ & $\begin{array}{l}\text { Guidelines and good } \\
\text { clinical practices }\end{array}$ & $\begin{array}{l}\text { To improve the quality of health care } \\
\text { professionals through the implemen- } \\
\text { tation of guidelines and to establish } \\
\text { specific criteria of accreditation of } \\
\text { the scientific societies authorized to } \\
\text { issue reference guidelines }\end{array}$ \\
\hline $\begin{array}{c}\text { Article } \\
6\end{array}$ & $\begin{array}{c}\text { Criminal liability of } \\
\text { health care professionals }\end{array}$ & $\begin{array}{l}\text { To establish new rules on criminal } \\
\text { liability of health care professionals, } \\
\text { partly decriminalizing their conducts }\end{array}$ \\
\hline $\begin{array}{c}\text { Article } \\
7\end{array}$ & $\begin{array}{l}\text { Civil responsibility of } \\
\text { public and private health } \\
\text { facilities and of health } \\
\text { care professionals }\end{array}$ & Fair compensation in case of harm \\
\hline $\begin{array}{c}\text { Articles } \\
8-14\end{array}$ & $\begin{array}{l}\text { Insurance aspects for } \\
\text { both public and private } \\
\text { health facilities and } \\
\text { professionals }\end{array}$ & $\begin{array}{l}\text { To create an easier insurance system } \\
\text { both for patients and physicians }\end{array}$ \\
\hline $\begin{array}{c}\text { Article } \\
15\end{array}$ & Expert witnesses & $\begin{array}{l}\text { To ensure the highest quality of } \\
\text { expert witness in medical liability } \\
\text { trials }\end{array}$ \\
\hline $\begin{array}{c}\text { Article } \\
16\end{array}$ & $\begin{array}{l}\text { New rules in the field of } \\
\text { clinical risk management }\end{array}$ & $\begin{array}{l}\text { To reinforce the programs of clinical } \\
\text { audit prohibiting access to any } \\
\text { document produced within risk } \\
\text { management activities for legal } \\
\text { actions against the clinician/hospital }\end{array}$ \\
\hline $\begin{array}{c}\text { Articles } \\
17,18\end{array}$ & $\begin{array}{c}\text { Financial invariance } \\
\text { clauses }\end{array}$ & \\
\hline
\end{tabular}




\section{ORGANIZATION OF PATIENT SAFETY AND NA- TIONAL OBSERVATORY INFORMATION SYSTEM}

With the aim to improve the quality and safety of healthcare it is necessary that each Italian regions establish centers for the clinical risk management and patient safety, structured with a multidisciplinary team in order to better approach complex problems $[14,15]$.

These centers should analyze and evaluate adverse events, send data to the National Observatory and elaborate recommendation for treatment safety in healthcare [16] with a systemic approach to the error $[17,18]$.

It concerns a great change that does not point out the attention on the single healthcare professional responsible for the adverse event, but also on the entire healthcare structure (procedures, technologies, human resources, personnel); in this logic, the human factor assumes a relevant part [16].

The new law provides two important aspects: a) the creation of a National Observatory which collects data coming from hospitals and the fact that report produced while performing an internal audit or internal investigations, cannot be used with judicial purposes.

\section{GUIDELINES, GOOD CLINICAL PRACTICES AND RECOMMENDATIONS}

Article 5 of the law establishes that health professionals should comply, as far as possible and within the bounds of each specific case, with the recommendations included in guidelines drafted by public and private healthcare organizations and institutions, as well as scientific societies and technical-scientific associations registered on the list compiled and regulated by Ministerial decree and updated every two years. In the absence of recommendations, healthcare professionals should follow the good clinical practice.

Since its first appearance in the Italian jurisprudence scenario, even before the final approval of the law, the terms "'guidelines and good practices" have become increasingly complex to interpret.

According to the 2011 definition developed by the Institute of Medicine (IOM), clinical guidelines are "Statements that include recommendations intended to optimize patient care that is informed by a systematic review of evidence and an assessment of the benefits and harms of alternative care options" [19].

The definition of good clinical practice (GCP) is more complicated. In Italy, a Ministerial Decree refers to "an international ethical and scientific quality standard for designing, recording and reporting trials that involve the participation of human subjects" [20]. The European Union Network for Patient and Quality of Care is drawing up a project to define and implement patient safety procedures, in conjunction with the Italian National Agency for Regional Health Services (AGENAS) as associated partner and National Contact Point. Patient safety practices have been defined as "those that reduce the risk of adverse events related to exposure to medical care across a range of diagnoses or conditions" [21]. Patient safety practices are transversal to clinical pathologies, the literature indicates the list of the ones strongly rec- ommended as evidence based, thus these are clearly indicated as to be applied in the framework of the new Italian law.

However, beyond the complexity of defining these terms, this article is one of the most significant of the law in that it encapsulates its dual concerns: on the one hand, the use of guidelines and good clinical practices as a further instrument for ensuring the quality of care and the safety of patients and, on the other, the fundamental role of guidelines in the assessment and judgment of the conduct of health professional.

With this in mind, clinical practice guidelines are based on clinical evidence and expert consensus to help decision making, defining standards of care, focusing efforts on improving quality and safety of care, and offering a way to disseminate evidence-based best practices [22-31].

In the area of quality of care, the implementation of guidelines and good clinical practice is aimed at various purposes. First, by definition, guidelines should provide health professionals with decision points that, combined with the physician's indispensable clinical judgement and the patient's preferences, will lead to the best decision for that patient in all aspects of patient care: prevention, diagnosis, treatment, rehabilitation, and palliative care [32-34]. At the broadest level, the implementation of clinical practice guidelines has, as it is well known, the potential to become an integral part of delivering quality care at an appropriate cost (Clutter), thereby constituting a major factor in quality assurance, quality improvement, medical audit, and similar procedures. It is noteworthy that clinical guidelines offer much to policymakers and health organizations at addressing key issues involving care quality and satisfaction, costs, and accountability in healthcare and public health. Thus they can be an increasingly important input in health policy analysis and decision-making [35].

Furthermore, the dual role of clinical guidelines is emphasized by law 24/2017 of which article 6 states: "Whenever incompetence is the cause of a patient's death or injury, it is not punishable as long as the guidelines have been followed or, in the absence of these, good clinical practice, provided that the guidelines are adequate for the specific case".

Aside from strictly juridical considerations which are beyond the scope of this paper, the question still remains of the influence of guidelines and GCP in Italian litigation.

Law 24/2017 establishes that the guidelines have to be developed by public and private institutions and by scientific and technical associations of health professionals registered on a list established and regulated by Decree of the Ministry of Health. This list will be updated every two years. In addition, the law provides that the guidelines and their updates are posted on the website of the ISS (High Italian Institute for Health), only after verification of the conformity of the methodology used to set standards and made public by the ISS as well as the relevance of scientific evidence to support the guidelines themselves. Furthermore, the law establishes the key criteria to use in evaluating scientific societies and the technical-scientific associations to be included in the official list: a) representation on the national territory; b) warranties of autonomy and independence of the members of the associations/societies; c) no profit organization; d) publication on the institutional web site of budgets, potential re- 
munerations, declaration and conflict of interest regulation, and identification of quality assurance and control systems for technical and scientific production; e) the verification of the maintenance of the required entry criteria.

It seems clear that the aim of the legislator is to offer more reliable benchmarking of the existing guidelines and clinical good practices compared to the past for both healthcare professionals and judges.

\section{THE PROBLEM WITH GUIDELINES}

Guidelines seek to achieve uniformity in standards of care, and thereby could provide physicians with "a shield" against lawsuits [36]. However, although guidelines are increasingly available, the attempt to immunize doctors who follow them strictly has largely failed [37].

The existence of a large number of clinical guidelines may provide physicians with a wide range of clinical choices. However, the considerable inconsistency and controversy of many existing guidelines may paradoxically leave clinicians feeling more exposed to claims of malpractice $[38,39]$, and the role of clinical guidelines in medical negligence litigation is still uncertain [40].

Despite the existence of guideline evaluation tools [4143], the quality of guidelines remains variable and may undermine their validity [44-47]. Lack of impartiality in the guidelines issuance process, conflicts of interest and obsolescence are other persistent problems affecting the quality and the authority of many existing guidelines [45-47]. Thus, the statement issued by the United States Congress Office of Technology Assessment seems to be still valid [48]: "if courts and legislatures are not selective about which guidelines are introduced as evidence, these conflicts may find their way into the courts and further confuse rather than clarify the process of determining negligence". The question remains: which guidelines can and should Italian doctors (and judges) believe in?

In Italy, as in many other countries, guidelines are issued by medical societies, non-profit disease organizations and other organisations. Before the approval of law 24/2017 in Italy there was no proper system of "accreditation" for guidelines although some progress has been made with the introduction of the National Guidelines System (NGLS), created in 2006 through an agreement between the Ministry of Health and the Italian National Institute of Health (ISS). The objective was to promote assessment processes and the improvement of diagnostic-therapeutic procedures through guidelines, and consensus conferences on urgent clinical problems [49,50]. However, the lack of a continuous and stable source of funding and the subsequent instability of the central structure were endangering all the knowledge and the experience gained during these years of activity. It was therefore crucial to guarantee and safeguard the role of a national, independent and public institution in the supervision of the guidelines development process and the provision of clinical governance [51].

Furthermore, besides these guidelines there are other ones formulated by regions and hospitals, resulting in a tangle of overlapping indications.
Other nations have national bodies to complete evidence reviews, issue guidelines for clinical practice and set national health care priorities. An example is the National Institute for Health and Care Excellence (NICE), which develops guidelines for the National Health Service (NHS) in England and Wales $[52,53]$. In the Netherlands, an organization facilitating the development of medical guidelines (CBO, Dutch Institute for Healthcare Improvement), is financed by the Order of Medical Specialists in collaboration with the Dutch College of General Practitioners. Since it was founded in 1979, more than 125 national guidelines have been published [54]. In the USA the Agency for Healthcare Research and Quality (AHRQ) is responsible for collecting CPGs and promoting their use [55].

At an international level, some authors suggest that guidelines can be considered of value if issued or certified by the government. However, such guidelines have some potential pitfalls: government-issued guidelines are seen as being anti-pluralist, anticompetitive and aiming at the rationing of health care $[56,57]$. Furthermore, national guidelines may ignore local differences and be unrealistic on a local basis. This may be particularly true in Italy where even today health disparities between regions abound [58,59]. Clinical guidelines drawn up at international and national levels may fail to take into account local constraints and situations although local adaptation could allow the potential hindrances in the implementation of CPGs to be overcome [56]. However, many years ago the IOM warned against the dangers of "parochial perspectives" by affirming that "local modifications of nationally produced guidelines will undermine one of the great benefits of these documents - standard approach to clinical problem solving" [56]. Guidelines written by local hospitals may be primarily concerned with cost containment and therefore lack sufficient sensitivity to patient safety. Furthermore, CPGs written by medical societies may be contaminated by conflicts of interest. Some authors suggest private for-profit companies creating and selling guidelines as a possible solution [56,57]. In such cases, to ensure the quality of the guidelines, patients should be able to seek remuneration from guideline-makers in the event that their recommendations prove to be substandard. However, further uncomfortable questions arise regarding this hypothesis: what if the company becomes insolvent? What compensation will the patient then? And should the responsibility be on the patient to pursue companies who promulgate sub-standard guidelines? Shouldn't be this a function of the state instead?

\section{DATA TRANSPARENCY}

A central aspect of patient protection is defined in article 4 dedicated to the issue of transparency. The law commits health organizations, both public and private, to make performance data publicly available, even in respect of the anonymity restrictions imposed by Italian legislation on privacy (Law 196/2003), and the data relating to all the compensation paid out in the last five years, as part of the work of monitoring, prevention and management of health risk. Moreover, personal data related to an episode of care must be accessible within one week upon the request from a patient or authorized family member, preferably in a digital 
format, thus pushing healthcare organization to move to an electronic patient record, with full traceability and readability of clinical information. Another important step in efforts towards transparency in the health system is a change in the previous regulation, making it possible for the next-of-kin of the deceased to come to an agreement with the hospital director to execute a post-mortem examination, in the presence of their physician of choice, both in the case of a death in the hospital as well as in any other place.

These regulations bring Italy into line in the drive towards increasing transparency within healthcare at personal, provider and structural level [60-62]. Public reporting web portals are spreading rapidly in several countries [63]. In the US, the CMS website Hospital Compare and many consumer reports, such as Healthgrades.org or ConsumerReports.org, make public the data on quality of care. In the UK, MyNHS and others enact the UK open data policy and the NHS quality transparency objectives. In Germany, the transparency portal Weisse Liste.de (WL.de) reports the results of the mandatory quality monitoring system $[64,65]$. To date, in Italy the National Outcomes Program (PNE - Piano Nazionale Esiti) provides a set of performance indicators based on administrative data at the hospital level and publicly available on the website of the National Agency for Healthcare Services (AGENAS). These data have been used for hospital rankings, despite the recommendation to consider these indicators, such as mortality after cardiac surgery, for further investigation into the quality and safety of care, given the known limitations of these kind of data [64]. Besides, since the launch of the National monitoring system on errors in healthcare (SIMES) in 2009, the Ministry of Health published five reports on sentinel events, while AGENAS recently released the first report on claims due to adverse events. In both cases, reports contain data aggregated per Region and are addressed to managers and health professionals rather than to the public. Some Regional Health Services and private health systems routinely release their own data on adverse events and on the application of safe practices, usually within an accreditation scheme.

The public reporting of performance information has several aims. The first one is to assist patients and users in making informed choices regarding care providers and health organizations, since the intrinsic value of choice in public services such as healthcare has long been recognized. Echoing Le Grand [66], choice is fundamental in bringing about, together with competition, improved outcomes, greater efficiency and the increased responsiveness of care providers. Choice policies can be used to improve access to providers or services, to encourage new entrants, and to send signals to care providers to improve their quality, efficiency and performance to attract and retain patients and users [67]. Choice can be an effective way to improve standards and quality in many areas, and public reporting of performance and quality information may encourage providers to improve the quality of their services, increasing provider accountability, identifying failures, and providing the public with reassurance over quality of care [63]. The ability of transparency to improve clinical outcome and quality has been widely demonstrated. How often patients use the public available data when mak- ing health care decisions, however, is not clear. Even so, several studies on public reporting suggest that quality information is rarely used by patients to make choices [68-72].

Also in Italy the process begins with recognition, at institutional level, of the fundamental importance of trust and candour between "users" (patients) and "providers" (healthcare professionals or organisations, so that before the publication of any data on patient safety, policies and practices are in place to ensure appropriate communication between professionals, patients and their families in case of an adverse event. Since 2014, the Italian code of medical ethics has stipulated that physicians have an ethical duty to inform the patient of each unwanted event and its causes, and to identify and report adverse events, near misses, and procedural and diagnostic errors [73,74]. Thus the obligation to supply information and to communicate continues to widen, in some way extending beyond the doctor/patient relationship to become an essential tool for improving the quality of professional services. A national guideline has been issued by the Ministry of Health [75] which emphasize that "Managing the relationship between health structures and patients on the occurrence of an adverse event demands a robust, clear, and well-defined approach. This should be based on a procedure shared by all the health structures of the National Health Service regarding both the management of the adverse event as well as open and transparent communication with patients and their families about what has happened". With a view to improving the quality of the health service and to managing clinical risk, the Ministry of Health specifies that "health workers have an ethical responsibility to maintain honest and transparent communication with patients and their families at all times during the healthcare process. This is particularly indispensable in the most difficult situations".

In the literature, some obstacles to the full effectiveness of transparency have been reported, such as the real relevance of the information publicly displayed [72,76]; the accuracy and adequacy of data reported (for example, measure content, the salience of the measures to consumers, or the quality of the data and analyses used to produce the measures) and how reports are formatted, presented, and delivered to users $[77,78]$, with particular concern for patients and users with lower health literacy. Taking into account these obstacles, the National Observatory on patient safety will be responsible to set the standards for public reporting, in terms of format and content according to the different target audience, in the perspective of international comparisons and exchanges of lessons learned from the analysis of adverse events and implementation of safe practices. In this regard, the WHO minimal information model for reporting and learning is a fundamental reference to record patient safety incidents [79], while the experience of the EU funded PASQ collaborative project can help to provide a valid format to monitor safe practices [80].

The real challenge for health institutions and organizations will be to increase the likelihood that public reporting of performance on patient safety is successful in achieving its goals, by implementing overarching strategies for increasing patient and user awareness of these tools of quality. 


\section{THE ROLE OF OMBUDSMAN AS A GUARANTOR FOR THE PATIENTS' RIGHT TO HEALTH IN CIVIL AND PENAL RIGHT}

The law aims to achieve the ambitious objective of protecting patients' health and safety by measures implemented in the various stages of care.

In the first stage, that of treatment and care, this is achieved through the implementation of safety systems, the introduction of the figure of the regional ombudsman as a guarantor for the patient's right to health and by calling for the application of good clinical/care practices and guidelines. Central challenges of the law are to ensure more extensive use of "standards of care" (i.e. guidelines or good clinical practice) to drive improvement in service performance, and to spread, among all the professional figures involved, a greater awareness that quality and patient safety cannot be achieved unless they are explicitly recognized as issues and targeted for action. In this sense, the law seems to call all citizens into meaningful and effective participation in health system safety. The figure of the regional ombudsman whom every citizen can freely address to report dysfunctions in the national health system (although no adverse events have occurred) acts as a bridge between patients/citizens and health institutions. This article of the law (art.2) has the potential to provide effective new ways (and perhaps new paradigms) of participation of all potential users of the national health system. Thus, in the intentions of the Italian legislator, the concept of clinical governance extends horizontally with citizen' participation and it seems to shift from an institutioncentered management towards a broader form, involving citizens, and endeavouring to obtain a whole picture of what leads or could lead to patient harm. Parallel to the rise of this model of governance is an increased emphasis on health institutions and policymakers' participation. An effective approach to clinical risk management requires healthcare organizations to gather information on risk and safety from a range of information sources so that key data sets can be assessed, helping to better understand and improve patient safety.

Before the endorsement of the law, the Italian judiciary system would adopt different approaches to medical malpractice law suits. On several occasions, Italian judges asserted that strict observance of the guidelines alone did not provide sufficient grounds for exoneration from liability, since circumstances could arise in an individual case in which the guidelines for similar cases were better ignored. In this case, observance of the guidelines might suggest negligence because of the particular nature of the illness and the conditions of the patient, since they could draw attention away from more appropriate clinical alternatives. In these specific cases, therefore, the guidelines did not provide the necessary prudence, diligence and attention required [81].

Other judgements highlighted the fact that lack of observance of the guidelines was not automatic proof of negligence since, depending on the particular clinical picture, non-observance of the guidelines might be necessary and desirable in order to ensure better health care for the patient. In these cases, the judges exonerated the doctor from liability because the guidelines, judged to be inappropriate for the clinical case in question, were not observed [82]. In other circumstances, doctors have been condemned for deviating from the guidelines without good reason [83] and others have been absolved because their work strictly followed the guidelines [84].

The analysis of numerous judgements prior to the introduction of the law underlined the issue that observance or not of guidelines was not a sufficiently clear-cut factor in assessing liability, but was rather only a guide for the judge when appraising the facts of a specific clinical case. Whether or not to comply with guidelines is a medical decision which Italian judges correctly assessed to be relevant, but not determinative, in reaching a verdict on malpractice.

In conclusion, even though the acceptance of clinical guidelines by Italian judges and attorneys gradually increased, they could not be held as binding, and liability would always be judged according to the case in question, rejecting the theory of unconditional faith in guidelines and underlining the necessity to verify their quality and strength.

It was into this case law scenario that, in 2012, a law on medical liability was introduced, now replaced by the recently approved law.

One of the earliest judgments subsequent to Law $189 / 2012$ tackled the question and stressed that the guidelines propose only general indications. They should, therefore, not be applied automatically, but only in relation to the specific features of every clinical case. It could thus happen that the professional might have to shape the guidelines to adapt them as circumstances arise and in some cases to bypass them completely [85].

\section{COMPENSATIONS AND INSURANCE COVERAGE}

When an adverse event occurs, resulting in injury to the patient, the law ensures that the latter is protected by adequate insurance cover. For example, all public and private healthcare institutions and all private practitioners are obliged to stipulate insurance contracts which aim to guarantee compensation to any such patients. Furthermore, simplified procedures are also delineated, at least in the intentions of the legislator, for obtaining compensation, though this topic is beyond the scope of this paper.

There were two scenarios in which health professionals might be found to be liable while observing guidelines: for errors committed while following indications contained in the guidelines, and for failure to bypass the guidelines when the case suggests a more personalized therapy suited to the specific patient.

Furthermore, the judges have highlighted on more than one occasion that the general definition of guidelines does not take their heterogeneity into account: they have different sources, varying degrees of trustworthiness, different specific objectives, methods which are not uniform, and varying degrees of compliance with evolving scientific knowledge. Some documents come from scientific companies, others from groups of experts, still others from public organizations and institutions, others from health organizations of various kinds. This diversity makes it clear that for physicians and for judges, the trustworthiness of guidelines is not guaranteed from the outset. It is essential to evaluate the characteristics of 
the person or community which has produced the guidelines, and to investigate that community's institutional identity and the degree to which it is independent of influential economic interests. Also important are the methods behind the guidelines, as well as the range and quality of the consensus surrounding them [86].

\section{APPOINTMENT OF THE TECHNICAL CON- SULTANTS OF THE COURT AND EXPERT WIT- NESSES IN THE JUDGMENTS OF HEALTH LIABIL- ITY}

References to guidelines and good clinical practices must be read in light of Article 15 of the law which deals with the issue of expert witnesses in professional malpractice trials. Along with other operational provisions that regulate the admission of expert witnesses to special registers provided by the Italian civil and criminal codes, the law explicitly states that, in professional malpractice trials, the judicial authority has the duty to engage a forensic specialist together with one or more other specialists who have specific and practical knowledge of the subject matter of the trial. Specific competence, professional experience and lack of conflict of interest are other specific criteria for the enrolment of expert witnesses on the registers, which have to be updated at least every five years.

These mandatory criteria finally bring the law into line with the Italian Code of Medical Ethics, establishing (art. 62) that: 1) The role of medical examiner requires high moral standing and professional awareness regarding the ethicallegal and deontological responsibilities involved and resistance to any kind of influence or pressure from external technical resources; 2) for any case examined there must be adequate medico-legal and scientific knowledge so that all judicial requirements for the case may be fulfilled and 3) in particularly complex cases the medical examiner may consult colleagues who have a proven history of experience and competence in the discipline.

The law, therefore, stresses one of the basic points that have, for several years now, enlivened international debate, i.e., the quality and trustworthiness of the expert witnesses in professional malpractice trials.

Furthermore, once and for all, it establishes that in medical malpractice litigation, the testimony of good and qualified expert witnesses' testimony is necessary. According to the Black's Law Dictionary, an expert witness is one "“qualified by knowledge, skill, experience, training, or education to provide a scientific, technical, or other specialized opinion about the evidence or a fact issue [87]. Law and medicine speak a different language [88], since medicine seeks to heal the sick by applying scientific knowledge pertaining to health and disease, while the law aims to resolve disputes in accordance with standards and rules that derive from legislation or prior judicial decisions [89].

The expert assesses medical information, interprets and explains medical research and customary practice to judges, and offers an expert opinion as to whether the standard of medical care was met, thus playing an invaluable role by interpreting complex medical scenarios for judges in cases of alleged negligence. A member of the profession (doctor or other health professional) is indispensable in explaining to judges the scientific and clinical aspects of the case, what the defending physician should have done or not done under the particular circumstances, whether such conduct constituted negligence by violating the standards of care of the profession and finally whether the breach of standards actually caused the patient's injury [90].

In this context, the experts' testimony is a critical element in litigation for alleged medical malpractice, as experts are asked for their qualified opinion to help judges establish the facts. Thus it has been hypothesized that the judicial trial on professional liability is a "battle of the experts" [91]. Judges are not bound by any expert opinion proffered during proceedings, having the powers of supervision and gatekeeping on expert witness' testimony; however, they are undoubtedly influenced by it.

Significantly, since the medical expert witness plays an important, often crucial, role in medical liability cases, his/her qualification may come under fire [92] and, at an international level, different responses have been proposed, all converging towards enhanced scrutiny of expert witnesses from both inside and outside the profession. State legislatures, state medical boards, and scientific and professional organizations have emerged as active regulators [93]. State oversight of expert medical testimony may consist in passing laws requiring out-of-state physicians to obtain a medical licence in that state in order to testify. Another system which provides oversight of medical expert testimony is the one operated by the medical profession in past decades through the increased involvement of medical professional societies in "policing" expert witness testimony by their members. Scientific societies and professional organizations, such as the American Medical Association [94,95] have adopted programmes that provide guidelines for members who serve as medical expert witnesses in professional liability cases and have advocated for the implementation of minimum statutory requirements for the qualifications of an expert witness, thus promoting scientifically sound expert witness testimony. However, some authors [93] argue that oversight by professional organizations could be problematic.

On the one hand it is indisputable that professional organizations are in a favourable position to ensure that experts accurately present specialist knowledge and practices: they have access to high levels of technical expertise, occupy powerful vantage points within their fields, and are often engaged in relevant pursuits, such as synthesis of evidence of best practices [93]. On the other hand, it is well known that in professional organizations there may be various conflict of interest [96].

The area of possible conflicts of interest is vast and highly polymorphous, the term itself is not always clear and univocal [97]. Broadly speaking, there is a conflict of interest when professional judgement concerning a primary interest tends to be unduly influenced by a secondary interest. In other words when a financial or intellectual relationship has the potential to condition the individual's ability to approach a scientific question with an open mind $[98,99]$. The following examples explain the different situations in which a conflict of interest may arise when a professional organization self regulates their own expert witness: " $i$. All financial 
relationships, including employment, consultancies, known stock holdings or holdings in a sector fund relevant to the subject matter, honoraria, in-kind gifts or benefits, endowments, patents, royalties, and paid expert testimony. Examples of in-kind gifts or benefits are travel, accommodation, meals, or frequent flier miles. ii. Personal, intellectual, or academic relationships that interfere with an individual's ability to consider or interpret the full breadth of available data or alternative points of view objectively. Examples include inability to review a grant, manuscript, or project proposal objectively due to competition for funding, timing of publication, or professional stature"' [99].

Furthermore, it cannot be ignored that professional societies have a deep fear of malpractice litigation and may be committed to reducing it [93]. Some authors would welcome the supervision of expert witnesses being entrusted to extramural bodies with no connection to either litigation side, within a state government agency or medical board. Other authors stand by different positions, stressing that the institution of an extramural body of control for expert witnesses could, not only be ineffective, but also antithetical [100]; nevertheless, an alternative method to evaluate medical testimony is comparing with standards determined by a survey of the relevant physician population [101].

The issue is still highly controversial and the real challenge for the Italian system will be to understand how the "specific and practical knowledge" and "professional expertise", as basic requisites for expert witnesses, will be assessed.

The future efforts of the Italian system will be to optimize two fundamental points: 1) the "message" provided by expert witness' testimony, by implementing the nationwide database of approved guidelines as a resource for reliable and authoritative guidelines, and 2) the "messengers' themselves" through a policy to choose which institution/board or organization will bear the burden of defining a "good" expert witness.

\section{CONCLUSION}

The law delineates a global patient care system [102], pointing to the opportunities for engagement and partnering of the healthcare system with health institutions, professional health associations, health training institutions, health associated civil society groups, and citizens.

At this point, it is necessary to quickly establish regional clinical risk management centres, let all the Italian healthcare trusts report event in a national reporting and learning system, introduce recommendations and safety practices to guarantee a good quality of care and monitor their application. National working groups are involved in identifying guidelines, methodologies and sharing safety tools that clinical risk management centres must disseminate and on which caregivers have to be trained in order to apply them correctly to prevent any possible harm to the patient, aware of working in order to ensure safety.

Furthermore, new perspectives could be related to the active role of patients and their families in the management of their own care because the law doesn't explore in detail and also it doesn't deal with sensitive aspects such as com- munication between patients and health professionals, despite communication failures being a leading cause of adverse events and litigation; it should also be noted that the recent law on informed consent clarified these aspects, closely related to the management of care.

\section{ETHICS APPROVAL AND CONSENT TO PARTICI- PATE}

Not applicable.

\section{HUMAN AND ANIMAL RIGHTS}

No Animals/Humans were used for studies that are base of this research.

\section{CONSENT FOR PUBLICATION}

Not applicable.

\section{AVAILABILITY OF DATA AND MATERIALS}

Not applicable.

\section{FUNDING}

None.

\section{CONFLICT OF INTEREST}

The authors declare no conflict of interest, financial or otherwise.

\section{ACKNOWLEDGEMENTS}

Declared none.

\section{AUTHORS' ROLES}

All Authors contributed equally to manuscript drafting and critical discussion and approved the final version.

\section{REFERENCES}

[1] Albolino, S.; Tartaglia, R.; Bellandi, T.; Bianchini, E.; Fabbro, G. Forni, S.; Cernuschi, G.; Biggeri, A. Variability of adverse events in the public health-care service of the Tuscany region. Intern. Emerg. Med., 2017, 12(7), 1033-1042.

[2] Di Landro, A.R. Criminal law as a response to medical malpractice: pluses and minuses--comparing Italian and U.S. experiences. Med. Law, 2012, 31, 221-263.

[3] Association of Insurance Companies. Association of Insurance Companies (ANIA) Executive Summary 2015-2016. www.ania.it/ Insurance Insurance/2015-2016/ANIA-Italian-Insurance-2015 16.pdf (Accessed January 19, 2018).

[4] Association of Insurance Companies. Association of Insurance Companies (ANIA) Executive Summary 2012-2013. www.agenas.it/images/agenas/monitor/quaderno/pdf/14 indagine sui_modelli_regionali_sinistri.pdf(Accessed January 19, 2018).

[5] Di Marzo, $\bar{C}$. Medical Malpractice: The Italian Experience. Chicago-Kent Law Rev., 2012, 87, 53-77.

[6] Traina, F. Medical malpractice: the experience in Italy. Clin. Orthop. Relat. Res., 2009, 467, 434-442.

[7] Elli, L.; Tenca, A.; Soncini, M.; Spinzi, G.; Buscarini, E.; Conte, D. Defensive medicine practices among gastroenterologists in Lombardy: between lawsuits and the economic crisis. Dig. Liver. Dis., 2013, 45, 469-473.

[8] Catino, M.; Celotti, S. The problem of defensive medicine: two Italian surveys. Stud. Health Technol. Inform., 2009, 148, 206-221. 
[9] Magnavita, N.; Fileni, A.; Mirk, P.; Magnavita, G.; Ricci, S.; Cotroneo, A.R. Malpractice claims in interventional radiology: frequency, characteristics and protective measures. Radiol. Med., 2013, 118, 504-517.

[10] Panella, M.; Rinaldi, C.; Leigheb, F.; Donnarumma, C.; Kul, S.; Vanhaecht, K.; Di Stanislao, F. The determinants of defensive medicine in Italian hospitals: The impact of being a second victim. Rev. Calid. Asist., 2016, 31, 20-25.

[11] Amaral Garcia, S.; Bertoli, P.; Grembi, V. Does experience rating improve obstetric practices? Evidence from Italy. Health Econ., 2015, 24(9), 1050-1064.

[12] Italian law 189/2012. http://www.gazzettaufficiale.it/eli/id/2012/ 11/10/012G0212/sg (Accessed January 19, 2018).

[13] Voultsos, P.; Casini, M.; Ricci, G.; Tambone, V.; Midolo, E.; Spagnolo, A.G. A proposal for limited criminal liability in highaccuracy endoscopic sinus surgery. Acta Otorhinolaryngol. Ital., 2017, 37(1), 65-71.

[14] Vincent, C.; Batalden, P.; Davidoff, F. Multidisciplinary centres for safety and quality improvement: learning from climate change science. BMJ Qual. Saf., 2011, 20, i73-78.

[15] Nuti, S.; Tartaglia, R.; Niccolai, F. Rischio clinico e sicurezza del paziente: modelli e soluzioni nel contesto internazionale; Il Mulino: Bologna, 2007.

[16] Bellandi, T.; Albolino, S.; Tartaglia, R.; Bagnara, S. Human Factors and Ergonomics in Patient Safety Management. In Human Factors and Ergonomics in Health Care and Patient Safety, $2^{\text {nd }}$ ed.; CRC Press Taylor \& Francis Group: Boca Raton, 2012.

[17] Bellandi, T.; Albolino, S.; Tomassini, C. How to create a safety culture in the healthcare system: the experience of the Tuscany Region. Theor. Issues Ergon. Sci., 2007, 8(5), 495-507.

[18] Bagnara, S.; Tartaglia, R. Patient safety: an old and a new issue. Theor. Issues Ergon. Sci., 2007, 8(5), 365-372.

[19] Graham, R.; Mancher, M.; Wolman, D.M.; Greenfield, S.; Steinberg, E. Clinical practice guidelines we can trust; National Academies Press: Washington (DC), 2011.

[20] Italian Ministry of Health, Decree 15 July 1997, "Transposition of European Union Guidelines on good clinical practice for clinical trials".

http://www.gazzettaufficiale.it/eli/id/1997/08/18/097A6330/sg (Accessed January 19, 2018).

[21] European Union Network for Patient Safety and Quality of Care (PaSQ). http://www.agenas.it/european-union-network-for-patientsafety-and-quality-of-care-pasq (Accessed January 19, 2018).

[22] Wetterneck, T.B.; Pak, M.H. Using clinical practice guidelines to improve patient care. WMJ, 2005, 104(3), 30-33.

[23] Rotter, T.; Kinsman, L.; James, E.; Machotta, A.; Gothe, H.; Willis, J.; Snow, P.; Kugler, J. Clinical pathways: effects on professional practice, patient outcomes, length of stay and hospital costs. Cochrane Database Syst. Rev., 2010, 17:CD006632.

[24] Medves, J.; Godfrey, C.; Turner, C.; Paterson, M.; Harrison, M.; MacKenzie, L.; Durando, P. Systematic review of practice guideline dissemination and implementation strategies for healthcare teams and team-based practice. Int. J. Evid. Based Healthc., 2010, $8,79-89$.

[25] Grimshaw, J.M.; Thomas, R.E.; MacLennan, G.; Fraser, C.; Ramsay, C.R.; Vale, L.; Whitty, P.; Eccles, M.P.; Matowe, L.; Shirran, L.; Wensing, M.; Dijkstra, R.; Donaldson, C. Effectiveness and efficiency of guideline dissemination and implementation strategies. Health Technol. Assess., 2004, 8, 1-72.

[26] Hakkennes, S.; Dodd, K. Guideline implementation in allied health professions: a systematic review of the literature. Qual. Saf. Health Care, 2008, 17, 296-300.

[27] Ivers, N.; Jamtvedt, G.; Flottorp, S.; Young, J.M.; Odgaard-Jensen, J.; French, S.D.; O'Brien, M.A.; Johansen, M.; Grimshaw, J.; Oxman, A.D. Audit and feedback: effects on professional practice and healthcare outcomes. Cochrane Database Syst. Rev., 2012, (6):CD000259.

[28] Baker, R.; Camosso-Stefinovic, J.; Gillies, C.; Shaw, E.J.; Cheater, F.; Flottorp, S.; Robertson, N.; Wensing, M.; Fiander, M.; Eccles, M.P.; Godycki-Cwirko, M.; van Lieshout, J.; Jäger, C. Tailored interventions to address determinants of practice. Cochrane Database Syst. Rev., 2015, (4):CD005470.

[29] Baskerville, N.B.; Liddy, C.; Hogg, W. Systematic review and meta-analysis of practice facilitation within primary care settings. Ann. Fam. Med., 2012, 10, 633-636.
[30] Brusamento, S.; Legido-Quigley, H.; Panteli, D.; Turk, E.; Knai, C.; Saliba, V.; Car, J.; McKee, M.; Busse, R. Assessing the effectiveness of strategies to implement clinical guidelines for the management of chronic diseases at primary care level in EU Member States: a systematic review. Health Policy, 2012, 107, 168-183.

[31] Flodgren, G.; Parmelli, E.; Doumit, G.; Gattellari, M.; O'Brien, M.A.; Grimshaw, J.; Eccles, M.P. Local opinion leaders: effects on professional practice and health care outcomes. Cochrane Database Syst. Rev., 2011, 10:CD000125.

[32] Di Sanzo, M.; Cipolloni, L.; Borro, M.; La Russa, R.; Santurro, A.; Scopetti, M.; Simmaco, M.; Frati, P. Clinical Applications of Personalized Medicine: A New Paradigm and Challenge. Curr. Pharm. Biotechnol., 2017, 18(3), 194-203.

[33] La Russa, R.; Fineschi, V.; Di Sanzo, M.; Gatto, V.; Santurro, A.; Martini, G.; Scopetti, M.; Frati, P. Personalized Medicine and Adverse Drug Reactions: The Experience of An Italian Teaching Hospital. Curr. Pharm. Biotechnol., 2017, 18(3), 274-281.

[34] Borro, M.; Gentile, G.; Cipolloni, L.; Foldes-Papp, Z.; Frati, P.; Santurro, A.; Lionetto, L.; Simmaco, M. Personalised Healthcare: The DiMA Clinical Model. Curr. Pharm. Biotechnol., 2017, 18(3), 242-252.

[35] Lohr, K.N.; Eleazer, K.; Mauskopf, J. Health policy issues and applications for evidence-based medicine and clinical practice guidelines. Health Policy, 1998, 46, 1-19.

[36] Sonnenberg, A.; Boardman, C.R. Costs of Fear. Am. J. Gastroenterol., 2013, 108, 173-175.

[37] Kachalia, A.; Little, A.; Isavoran, M.; Crider, L.M.; Smith, J. Greatest impact of safe harbor rule may be to improve patient safety, not reduce liability claims paid by physicians. Health Aff. (Millwood), 2014, 33, 59-66.

[38] Kachalia, A.; Mello, M.M. Breast cancer screening: conflicting guidelines and medicolegal risk. JAMA, 2013, 309, 2555-2556.

[39] Mehlman, M.J. Medical practice guidelines as malpractice safe harbors: illusion or deceit? J. Law Med. Ethics, 2012, 40, 286-300.

[40] Samanta, A.; Mello, M.M.; Foster, C.; Tingle, J.; Samanta, J. The role of clinical guidelines in medical negligence litigation: a shift from the Bolam standard? Med. Law Rev.; 2006, 14, 321-366.

[41] AGREE Collaboration. Development and validation of an international appraisal instrument for assessing the quality of clinical practice guidelines: the AGREE project. Qual. Saf. Health Care, 2003, 12, 18-23.

[42] Balshem, H.; Helfand, M.; Schünemann, H.J.; Oxman, A.D.; Kunz, R.; Brozek, J.; Vist, G.E.; Falck-Ytter, Y.; Meerpohl, J.; Norris, S.; Guyatt, G.H. GRADE guidelines: 3. Rating the quality of evidence. J. Clin. Epidemiol., 2011, 64, 401-406.

[43] Schünemann, H.J.; Wiercioch, W.; Brozek, J.; EtxeandiaIkobaltzeta, I.; Mustafa, R.A.; Manja, V.; Brignardello-Petersen, R.; Neumann, I.; Falavigna, M.; Alhazzani, W.; Santesso, N.; Zhang, Y.; Meerpohl, J.J.; Morgan, R.L.; Rochwerg, B.; Darzi, A.; Rojas, M.X.; Carrasco-Labra, A.; Adi, Y.; AlRayees, Z.M.; Riva, J.; Bollig, C.; Moore, A.; Yepes-Nuñez, J.J.; Cuello, C.; Waziry, R.; Akl, E.A. GRADE Evidence to Decision Frameworks for adoption, adaptation and de novo development of trustworthy recommendations: GRADE-ADOLOPMENT. J. Clin. Epidemiol., 2017, $81,101-110$.

[44] Guyatt, G.H.; Oxman, A.D.; Kunz, R.; Vist, G.E.; Falck-Ytter, Y.; Schunemann, H.J. What is actuality of evidence and why is it important to clinicians? BMJ, 2008, 336, 995-998.

[45] Kung, J.; Miller, R.R.; Mackowiak, P.A. Failure of clinical practice guidelines to meet institute of medicine standards: Two more decades of little, if any, progress. Arch. Intern. Med., 2012, 172, 16281633.

[46] Laine, C.; Taichman, D.B.; Mulrow, C. Trustworthy clinical guidelines. Ann. Intern. Med., 2011, 154, 774-775.

[47] Qaseem, A.; Forland, F.; Macbeth, F.; Ollenschläger, G.; Phillips, S.; van der Wees, P. Board of Trustees of the Guidelines International Network. Guidelines International Network: toward international standards for clinical practice guidelines. Ann. Intern. Med., 2012, 156, 525-531.

[48] US Office of Technology Assessment. Impact of Legal Reform on Medical Malpractice Costs. http://ota.fas.org/reports/9329.pdf (Accessed January 19, 2018).

[49] Grilli, R. Toward the efficacy of clinical appropriateness: national program for guidelines. Epidemiol. Prev., 2000, 24, 54-56.

[50] Grilli, R.; Taroni, F. Guidelines: several principles of the National Program. Rec. Prog. Med., 2000, 91, 341-343. 
[51] Mele, A.; D'Angelo, F.; Della Seta, M.; Lacorte, E.; Laricchiuta, P.; Morciano, C.; De Masi, S. National Guidelines System: the Italian experience. Epidemiol. Prev., 2014, 38, 53-58.

[52] Keyhani, S.; Kim, A.; Mann, M.; Korenstein, D. A new independent authority is needed to issue National Health Care guidelines. Health Aff. (Millwood), 2011, 30, 256-265.

[53] National Institute for Health and Care Excellence. The Guidelines Manual; National Institute for Health and Care Excellence (NICE): London, 2012.

[54] Poolman, R.W.; Verheyen, C.C.; Kerkhoffs, G.M.; Bhandari, M.; Schunemann, H.J.; International Evidence-Based Orthopedic Surgery Working Group. From evidence to action: Understanding clinical practice guidelines. Acta Orthop., 2009, 80, 113-118.

[55] Avrahan, R. Clinical Practice Guidelines: The Warped Incentives in the U.S. Healthcare System. Am. J. Law Med., 2011, 37, 7-40.

[56] Tzeel, A. Clinical Practice Guidelines and Medical Malpractice. Physician Exec., 2002, 28, 36-39.

[57] Rosoff, A.J. Evidence-Based Medicine and the Law: The Courts Confront Clinical Practice Guidelines. J. Health Polit. Policy Law, 2001, 26, 327-368.

[58] Nonino, F.; Liberati, A. Essential requirements for practice guidelines at national and local levels. Neurol. Sci., 2004, 25, 2-7.

[59] Franzini, L.; Giannoni, M. Determinants of health disparities between Italian regions. BMC Public Health, 2010, 10, 296-306.

[60] Wahid, N.N.; Moppett, S.H.; Moppett, I.K. Quality of Quality Accounts: transparency of public reporting of Never Events in England. A semi-quantitative and qualitative review. J. R. Soc. Med., 2016, 109, 190-199.

[61] Austin, J.M.; McGlynn, E.A.; Pronovost, P.J. Fostering Transparency in Outcomes, Quality, Safety, and Costs. JAMA, 2016, 316, 1661-1662.

[62] Kachalia, A. Improving patient safety through transparency. $N$. Engl. J. Med., 2013, 369, 1677-1679.

[63] Kumpunen, S.; Trigg, L.; Rodrigues, R. Public reporting in health and long-term care to facilitate provider choice. http://www. euro.who.int/en/about-us/partners/observatory/publications/policybriefs-and-summaries/public-reporting-in-health-and-long-termcare-to-facilitate-provider-choice (Accessed January 19, 2018).

[64] Pross, C.; Averdunk, L.H.; Stjepanovic, J.; Busse, R.; Geissler, A. Health care public reporting utilization - user clusters, web trails, and usage barriers on Germany's public reporting portal WeisseListe.de. BMC Med. Inform. Decis. Mak., 2017, 17, 48

[65] Bellandi, T.; Tartaglia, R.; Forni, S.; D'Arienzo, S.; Tulli, G. Adverse events in cardiac surgery, a mixed methods retrospective study in an Italian teaching hospital. J. Eval. Clin. Pract., 2017, 23, 839-847.

[66] Le Grand, J. The other invisible hand: delivering public services through choice and competition; Princeton University Press: Princeton, 2007

[67] Baxter, K.; Glendinning, C.; Greener, I. The implications of personal budgets for the home care market. Public Money \& Management, 2011, 31, 91-98.

[68] Marshall, M.N.; Shekelle, P.G.; Leatherman, S.; Brook, R.H. The public release of performance data: what do we expect to gain? A review of the evidence. JAMA, 2000, 283, 1866-1874

[69] Fung, C.H.; Lim, Y.W.; Mattke, S.; Damberg, C.; Shekelle, P.G. Systematic review: the evidence that publishing patient care performance data improves quality of care. Ann. Intern. Med., 2008, 148, 111-123.

[70] Shekelle, P.G.; Lim, Y.W.; Mattke, S.; Damberg, C. Does public release of performance results improve quality of care? A systematic review; The Health Foundation: London, 2008.

[71] Ketelaar, N.A.; Faber, M.J.; Flottorp, S.; Rygh, L.H.; Deane, K.H.; Eccles, M.P. Public release of performance data in changing the behaviour of healthcare consumers, professionals or organisations. Cochrane Database Syst. Rev., 2011, (11):CD004538.

[72] Victoor, A.; Delnoij, D.M.; Friele, R.D.; Rademakers, J.J. Determinants of patient choice of healthcare providers: a scoping review. BMC Health Serv. Res., 2012, 12, 272.
[73] Turillazzi, E.; Neri, M. Medical error disclosure: from the therapeutic alliance to risk management: the vision of the new Italian code of medical ethics. BMC Med. Ethics, 2014, 15, 57.

[74] D'Errico, S.; Pennelli, S.; Colasurdo, A.P.; Frati, P.; Sicuro, L.; Fineschi, V. The right to be informed and fear of disclosure: sustainability of a full error disclosure policy at an Italian cancer centre/clinic. BMC Health Serv. Res.; 2015, 15, 130.

[75] Italian Ministry of Health. "Guidelines for the Management and Communication of Adverse Events in Health", 2011.

[76] Yahanda, A.T.; Lafaro, K.J.; Spolverato, G.; Pawlik, T.M. A Systematic Review of the Factors that Patients Use to Choose their Surgeon. World J. Surg., 2016, 40(1), 45-55.

[77] Sinaiko, A.D.; Eastman, D.; Rosenthal, M.B. How report cards on physicians, physician groups, and hospitals can have greater impact on consumer choices. Health Aff. (Millwood), 2012, 31(3), 602611.

[78] Findlay, S.D. Consumers' Interest In Provider Ratings Grows, And Improved Report Cards And Other Steps Could Accelerate Their Use. Health Aff. (Millwood), 2016, 35(4), 688-696.

[79] World Health Organization. Minimal Information Model for Patient Safety. http://www.who.int/patientsafety/implementation/ information_model/en/ (Accessed January 29, 2018).

[80] European Union PaSQ Joint Action. Patient Safety and Quality of Care. http://www.pasq.eu/ (Accessed January 29, 2018)

[81] Italian Supreme Court, Section IV, Judgment n. 4391, 2012.

[82] Italian Supreme Court, Section V, Judgment n. 33136, 2011.

[83] Italian Supreme Court, Section IV, Judgment n. 34729, 2011

[84] Italian Supreme Court, Section IV, Judgment n. 23146, 2012.

[85] Italian Supreme Court, Section IV, Judgment n. 16237, 2013

[86] Italian Supreme Court, Section IV, Judgment n. 16237, 2013

[87] Garner, B.A. Black's Law Dictionary, $9^{\text {th }}$ ed.; Thomas West: New York, 2009.

[88] Cheshire, W.P.; Hutchins, J.C. Professionalism in court: The neurologist as expert witness. Neurol. Clin. Pract., 2014, 4, 335-341.

[89] Jones, O.D.; Wagner, A.D.; Faigman, D.L.; Raichle, M.E. Neuroscientists in court. Nature, 2013, 14, 730-736.

[90] Bal, B.S. The expert witness in medical malpractice litigation. Clin Orthop. Relat. Res., 2009, 467, 383-391.

[91] Pegalis, S.E. Medical Malpractice: The Art of Advocacy When Engaging In The "Battle of the Experts". Am. J. Trial Advoc., 1999, 23, 2.

[92] Johnston, J.C.; Sartwelle, T.P. The expert witness in medical malpractice litigation: through the looking glass. J. Clin. Neurol., 2013, $28,484-450$

[93] Kesselheim, A.S.; Studdert, D.M. Role of professional organizations in regulating physician expert witness testimony. JAMA, 2007, 298, 2907-2909.

[94] American Medical Association. AMA expert witness testimony policy $\mathrm{H}-265.994$.

[95] American Medical Association. AMA expert witness testimony policy E-9.07.

[96] Camilleri, M.; Parke, D.W. $2^{\text {nd }}$. Perspective: Conflict of interest and professional organizations: considerations and recommendations. Acad. Med., 2010, 85, 85-91.

[97] Foster, R.S. Conflicts of interest: recognition, disclosure, and management. J. Am. Coll. Surg., 2003, 196, 505-517.

[98] Schunemann, H.J.; Osborne, M.; Moss, J.; Manthous, C.; Wagner, G.; Sicilian, L.; Ohar, J.; McDermott, S.; Lucas, L.; Jaeschke, R. An official American Thoracic Society Policy statement: managing conflict of interest in professional societies. Am. J. Respir. Crit. Care Med., 2009, 180, 564-580.

[99] American Thoracic Society. Ethics and Conflict of Interest Committee and the Documents Development and Implementation Committee. https://www.thoracic.org/about/governance/ethics-andcoi/ (Accessed January 29, 2018).

[100] Larriviere, D.; Williams, M.A.; Sagsveen, M. Regulating physician expert witness testimony. JAMA, 2008, 299, 1667.

[101] Hartz, A.J.; Green, M. Regulating physician expert witness testimony. JAMA, 2008, 299, 1667-1668.

[102] Bellandi, T.; Tartaglia, R.; Sheikh, A.; Donaldson, L. Italy recognises patient safety as a fundamental right. $B M J, \mathbf{2 0 1 7}, 357: \mathrm{j} 2277$. 